\title{
Base Erosion, Profit Shifting and Developing Countries
}




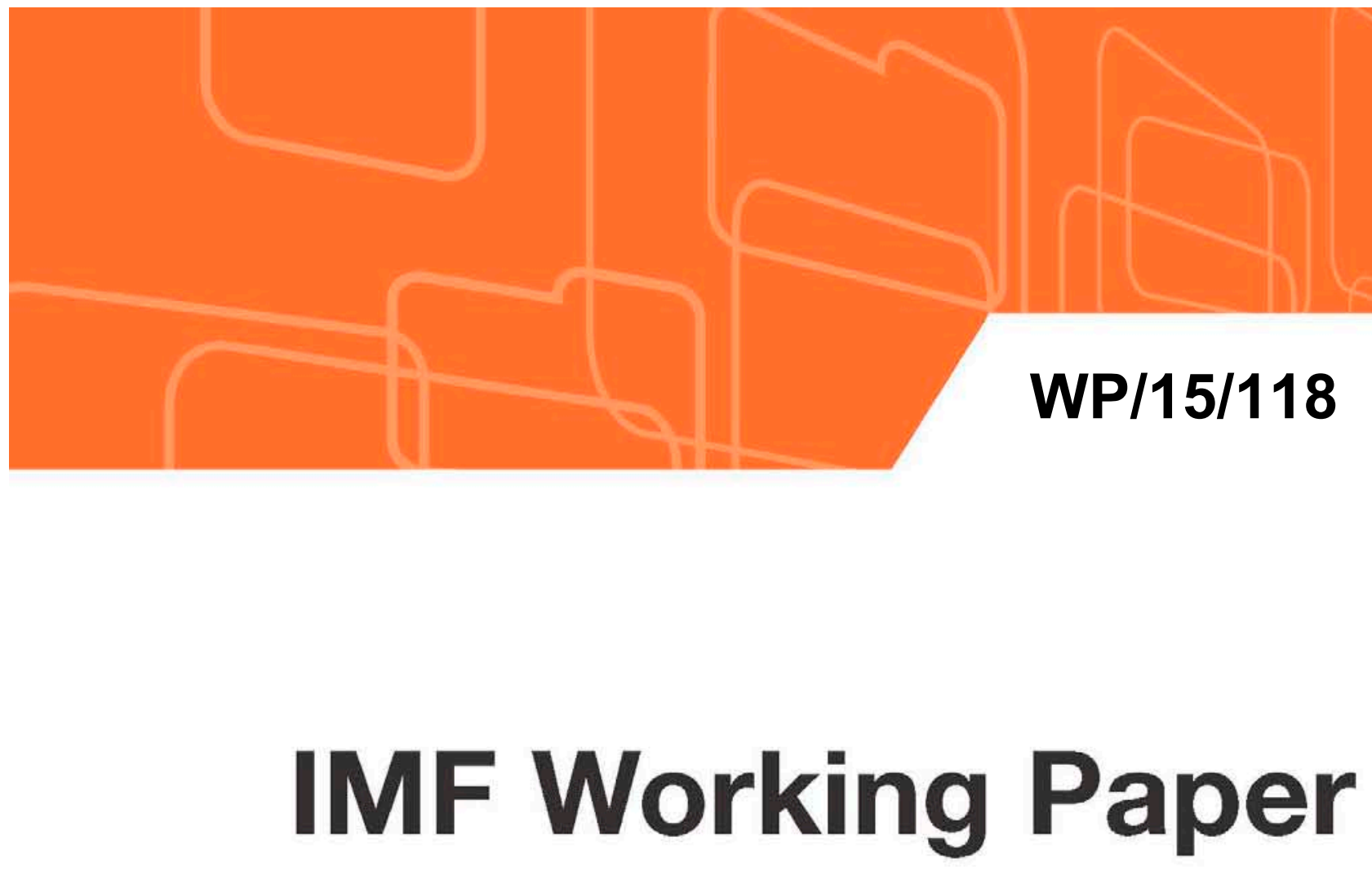

Base Erosion, Profit Shifting and Developing Countries

by Ernesto Crivelli, Ruud De Mooij and Michael Keen

I N T E R N A T I O N A L M O NETAR Y FU N D 


\title{
IMF Working Paper
}

Fiscal Affairs Department

\section{Base Erosion, Profit Shifting and Developing Countries ${ }^{1}$ \\ Prepared by Ernesto Crivelli, Ruud De Mooij and Michael Keen}

May 2015

\section{This Working Paper should not be reported as representing the views of the IMF.} The views expressed in this Working Paper are those of the author(s) and do not necessarily represent those of the IMF or IMF policy. Working Papers describe research in progress by the author(s) and are published to elicit comments and to further debate.

\begin{abstract}
International corporate tax issues are now prominent in public debate, most notably with the current G20-OECD project addressing Base Erosion and Profit Shifting ('BEPS'). But, while there is considerable empirical evidence for advanced countries on the cross-country fiscal externalities at the heart of these issues, there is almost none for developing countries. This paper uses panel data for 173 countries over 33 years to explore the magnitude and nature of international fiscal externalities, with a particular focus on developing countries and applying a new method enabling a distinguishing between spillover effects through real investment decisions and through avoidance techniques - and quantification of the revenue impact of the latter. The results suggest that spillover effects on the tax base are substantially larger in developing countries than in advanced, and that they imply a likely loss of revenue from BEPS that is both substantially larger for them.
\end{abstract}

JEL Classification Numbers: F21; F23; H25.

Keywords: Corporate income tax; BEPS; tax avoidance; international taxation.

Author's E-Mail Address: ECrivelli@imf.org; RDeMooij@imf.org; MKeen@imf.org

\footnotetext{
${ }^{1}$ This paper builds on IMF (2014). We are grateful to Tarun Narashimhan for assistance with the data, and to seminar participants and colleagues for many helpful comments and suggestions. Errors and view are ours alone.
} 


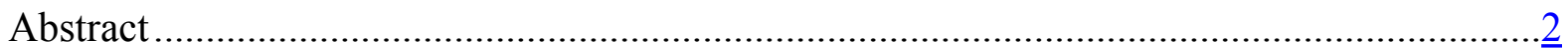

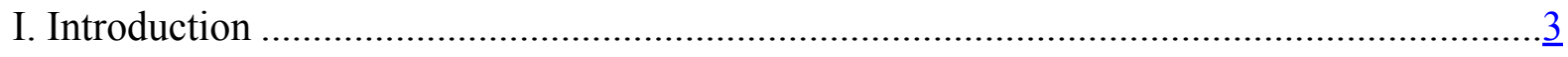

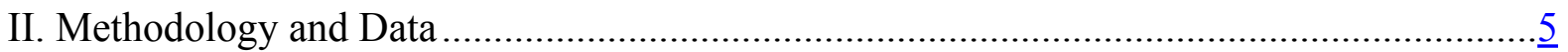

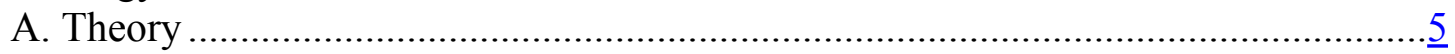

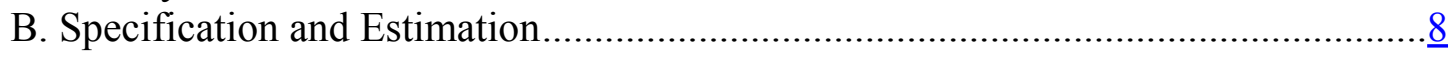

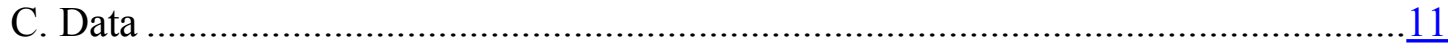

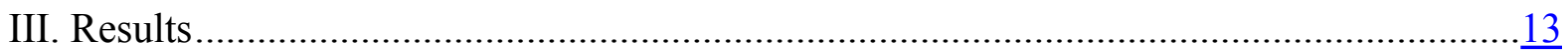

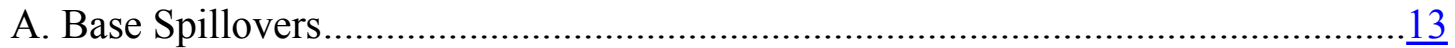

B. The Revenue Cost of BEPS ..................................................................... $\frac{19}{20}$

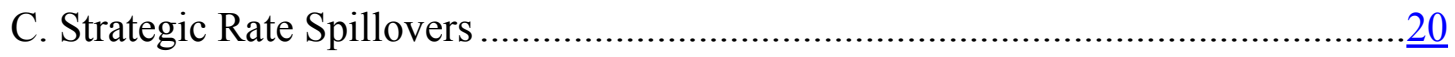

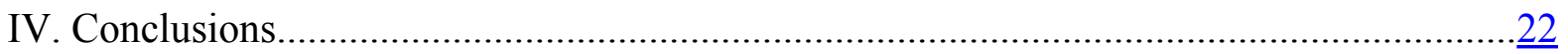

Tables

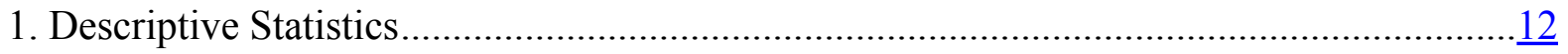

2. Base Spillovers with Alternative Weighting Matrices................................................14

3. Base Spillovers by Income Level, 'Haven'-Weighted ............................................... $\frac{16}{18}$

4. Base Spillovers in Developing Countries .............................................................18

5. Including both GDP- and Haven-weighted Averages ..............................................

6. Illustrative Revenue Loss Calculations...................................................................

7. Strategic Rate Spillovers, Alternative Weighting Matrices ..........................................21

8. Strategic Rate Spillovers by Income Level, Inverse-Distance Weighted ...........................22

Figures

1. Revenue from the Corporate Income Tax, in Percent of Total Revenue ............................ 4

2. Corporate Income Tax Rates, 1980-2013 …................................................................13

Appendixes

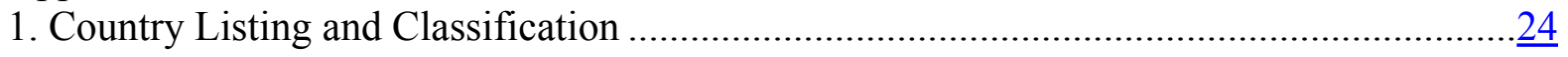

2. Results Using Average Effective Tax Rates.......................................................... 25

Appendix Table

1. Base and Strategic Rate Spillovers, using AETR ......................................................

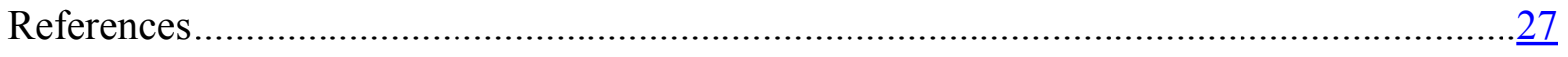




\section{INTRODUCTION}

International aspects of corporate taxation have recently come to prominence in public debate, prompted largely by increased awareness of the relatively low amounts of tax that, as a result of cross-border tax planning, many multinational enterprises pay. The issue itself, of course, is not new. What is new is the attention it is receiving from policy makers. Most notably, the G20-OECD project (OECD, 2013) on base erosion and profit shifting ('BEPS'), envisaging action in fifteen areas, is an unparalleled effort to strengthen the international corporate tax system by limiting opportunities for avoidance by multinationals. More broadly too there is an increased awareness of the intensity of international tax competition, and the possibility of mutual harm from the attempts of each country to make its tax system more attractive than those of others, both for real investment and for avoidance purposes.

These concerns with current international corporate tax arrangements have arisen most prominently in advanced economies. It is they that drive the BEPS process. ${ }^{2}$ Clearly, however, these concerns may be ones for developing countries too. There is substantial experience, for instance, of even single international tax cases involving what are for these countries very significant amounts of revenue (IMF, 2014). ${ }^{3}$ And indeed developing countries tend to be more reliant on the corporate income tax as a share of all tax revenue than are higher income countries, as Figure 1 shows, and with fewer realistic alternative sources of revenue. All this suggest that developing countries may well be more vulnerable to erosion of the corporate tax base. There has been, however, no broad empirical assessment of the significance of these issues for developing countries. The primary purpose of this paper is to provide systematic empirical evidence on this, and to quantify the possible effects. Put simply, the question addressed is: Do BEPS, and tax competition, really matter for developing countries? ${ }^{4}$ The answer, to anticipate, is that they do-and quite possibly even more than they do for advanced countries.

The analysis focuses on two distinct types of cross-border fiscal externality, or spillover, in international corporate taxation: 'base' and 'strategic' spillovers. By 'base spillover' is meant the impact of one country's tax policy on the tax bases of other countries. This can arise through either an impact on real activities (through investment and the like) and/or the shifting of paper profits. One of the contributions below is to develop and apply an approach

\footnotetext{
${ }^{2}$ Though important steps are being taken to involve developing countries in the BEPS process.

${ }^{3}$ Civil society has also drawn attention to particular instances, as for example in Action Aid (2010) (on which see also Schatan (2012)). OECD (2014) takes stock of specific BEPS action items most relevant for developing countries.

${ }^{4}$ Results here relating to effects on 'developing countries' refer to the subset of low and middle income countries (as classified by the World Bank) listed in Appendix 1 for which the necessary data are available other than those (listed in footnote 12) that are resource-rich.
} 
Figure 1. Revenue from the Corporate Income Tax, in Percent of Total Revenue

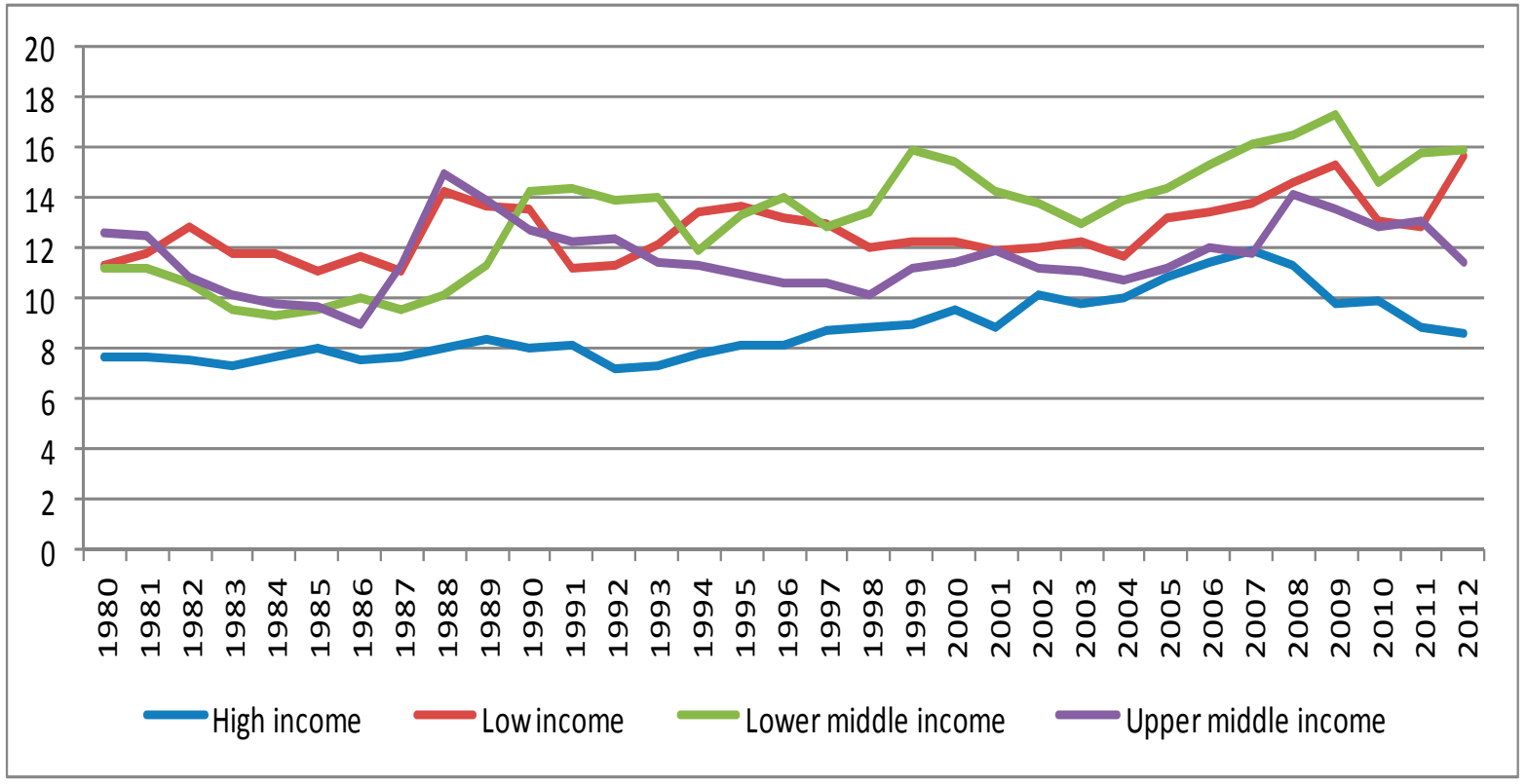

Source: IMF Staff estimates; data from IMF's Fiscal Affairs Department database.

Note: Total tax revenue including grants and excluding social contributions; resource-rich countries excluded.

enabling some disentangling of the two. By strategic rate spillovers is meant the impact on a country's policy choices of tax changes abroad: tax competition, in its broadest sense.

For advanced economies, there is a wealth of evidence on the magnitude of base spillovers. One strand of research looks at such spillovers through the allocation of real investments; a meta study by De Mooij and Ederveen (2008) suggests that a 10 percentage point reduction in a country's average effective tax rate increases its stock of FDI, on average and in the long run, by over 30 percent. Another strand looks at base spillovers through profit shifting, without an underlying shift in real capital; Heckemeyer and Overesch (2013) report a consensus semi-elasticity of -0.8 , implying that a 10 percentage point higher tax rate will reduce reported profit in an affiliate by 8 percent. And a rapidly growing number of studies, recently reviewed by Dharmapala (2014), explore more closely the various types of profit shifting that are used. What is absent from the existing literature, however, is similarly systematic evidence for developing countries.

In terms of strategic rate spillovers too, the evidence relates almost entirely to advanced economies: Devereux et al. (2008) find, for instance, that among OECD countries a 10 percentage point decrease in the statutory CIT rates in other countries generates, on average, a cut of 7 percentage points in response. ${ }^{5}$ The exception is Klemm and Van Parys (2012), who estimate fiscal reactions among Sub-Saharan African and Caribbean countries.

\footnotetext{
${ }^{5}$ See also the review in Leibrecht and Hochgatterer (2012).
} 
They report smaller but significant strategic interactions in statutory corporate tax rates, in the order of 2.5 to 3 points in response to a 1 point tax cut abroad.

This paper aims to assess the size and significance of base and strategic rate spillovers, within an approach that provides some handle on the distinction between real and profitshifting channels of effect - and in doing this to concentrate especially on the perspective of developing countries. ${ }^{6}$ The focus is especially on base spillovers, since these relate directly to current policy focus on BEPS; and indeed the approach adopted here enables an estimate, albeit very speculative, of the revenue impact of international corporate tax avoidancesomething the literature has struggled to do in a coherent way. To this end, we exploit aggregate data on corporate tax bases for a panel of 120 countries (and tax rates for 173 countries), over the period 1980-2013.

The next section sets out a framework for distinguishing the two distinct channels by which base spillovers can operate, discusses estimation strategy and describes the data. Section III reports results, including the implied revenue impact of BEPS activities involving tax 'havens'. Section IV concludes.

\section{Methodology ANd DATA}

\section{A. Theory}

This section sets out a simple framework to guide the empirics, pointing to a strategy for distinguishing between two types of corporate tax base spillover: through the allocation of real investment, and through profit shifting. It does so by adding the possibility of profit shifting to the standard model for analyzing international tax effects of real investment (Zodrow and Mieskowski (1986) and Wilson (1986)).

Consider then a world of $n$ countries, with country $i$ populated by a fixed number $h_{i}$ of identical individuals who each supply one unit of labor (measured in efficiency units). The world population is normalized to unity $\left(\sum_{j=1}^{n} h_{j}=1\right)$, so that $h_{i}$ measures the relative 'size' of country $i$.

Production, and profit shifting, are undertaken by a single representative multinational. This has a single affiliate in each country, the revenue generated by its real activities in $i$ being characterized by the function $f_{i}\left(k_{i}\right)$, where $k_{i}$ is the capital-labor ratio (and $h_{i} k_{i}$ therefore the

\footnotetext{
${ }^{6}$ Other studies, such as Clausing (2007), Brill and Hassett (2007) and Devereux (2007) have explored how corporate tax revenues (relative to GDP) vary with countries' own statutory CIT rates. Abbas and Klemm (2013) perform a similar analysis for 50 developing countries. The empirical results reported here of course have implications for that question, too, but for brevity, this is not pursued below.
} 
total amount of capital in $i$ ), and $f_{i}$ is output per worker, with $f_{i}^{\prime}>0$ and $f_{i}^{\prime \prime}<0$. The total capital available to the firm, to allocate across the $n$ jurisdictions, is fixed at $\bar{k}=\sum_{j=1}^{n} h_{j} k_{j}$. The multinational may also shift tax base between its affiliates operating in the various countries: the base shifted into $i$ from $j$ is denoted by $s_{i j}=-s_{j i}$, with $s_{i i}=0$. There is some cost to doing so, however; this cost, assumed to be independent of the location of real capital, is denoted by $c_{i j}\left(s_{i j}\right)$, with $c_{i j}^{\prime}$ strictly positive (negative) as $s_{i j}$ is strictly positive (negative) and $c_{i j}^{\prime \prime}>0$.

The government in each country employs only a source-based tax on capital, ${ }^{7}$ at rate $t_{i}$, the base of which is the sum of real capital located in $i$ and base shifted into $i$ :

$$
b_{i}=h_{i} k_{i}+\sum_{j=1}^{n} s_{i j}
$$

Denoting by $\rho$ the world (tax-exclusive) interest rate, which the multinational takes as given — or alternatively, interpreting $\rho$ as the shadow value of the multinational's aggregate capital - and assuming for simplicity that the costs of base-shifting are not tax-deductible, the multinationals' after-tax profit is:

$$
\Pi=\sum_{i=1}^{n}\left\{h_{i} f_{i}\left(k_{i}\right)-\rho h_{i} k_{i}-t_{i}\left(h_{i} k_{i}+\sum_{j \neq i}^{n} s_{i j}\right)-\sum_{j \neq i}^{n} c_{i j}\left(s_{i j}\right)\right\} .
$$

The multinational thus has two decisions to take: the allocation of its real capital across countries; and the artificial shifting of tax base between them. We consider each of these, and the quite different ways in which they are affected by taxation, in turn.

Taking first the allocation of real capital, (2) implies the necessary conditions:

$$
f_{i}^{\prime}\left(k_{i}\right)=\rho+t_{i}, \quad \mathrm{i}=1, \ldots, n
$$

This simply says that the multinational will allocate its capital to equalize the after-tax return across its affiliates: otherwise, it could earn more by reallocating assets to wherever the aftertax return is greatest. Equation (3) implicitly defines the capital thus allocated to $i$ as a function $k_{i}\left(t_{i}, \rho\right)$ of the tax rate in $i$ and the world interest rate (decreasing in both). The condition that all capital be allocated, $\sum_{j=1}^{n} h_{j} k_{j}\left(t_{j}, \rho\right)=\bar{k}$, then defines $\rho$ as a function of all tax rates, and hence the capital allocation to each country as a function $k_{i}\left(t_{1}, \ldots, t_{n}\right)$ of all tax

\footnotetext{
${ }^{7}$ A richer treatment would differentiate between one tax directed to the use of capital and another on profits attributed to each jurisdiction. These would then act differently on real investment decisions and base shifting (along the lines of Keen and Konrad (2013)). Though it is somewhat artificial to think of base shifting in terms of apparent amounts of real capital employed rather than attributed profits, the single instrument specification here suffices, given limitations on the tax rate data available, for the central purpose of guiding the empirics.
} 
rates. The structure of tax effects this implies are complex. One key driver emerges clearly, however, on supposing each production function to be quadratic (perhaps with different parameters). For this case, Keen and Konrad (2013) show that:

$$
\begin{aligned}
& \frac{\partial k_{i}}{\partial t_{i}}=-\left(1-h_{i}\right)<0 \\
& \frac{\partial k_{i}}{\partial t_{j}}=h_{j}>0 .
\end{aligned}
$$

Size thus plays a critical role in determining the magnitude of both own and cross-border tax effects. The increase in real investment in $i$ consequent upon a tax change in some other country $j$, for instance, is greater the larger is country $j$. This has evident intuitive appeal: one would not, for instance, expect real investment in a major advanced economy to be much affected by the tax rate set by a small island economy.

The same is not true, however when it comes to base shifting. Turning to this second dimension of the multinational's decisions, the first-order condition with respect to $s_{i j}$ (recalling that this also appears as $-s_{j i}$ ) is

$$
c_{i j}^{\prime}\left(s_{i j}\right)-c_{j i}^{\prime}\left(s_{i j}\right)=t_{j}-t_{i} \quad \forall i, \forall j \neq i \text { such that } t_{j}>t_{i}
$$

The multinational thus shifts base from a high tax jurisdiction $j$ into $i$ until the tax saved on the marginal dollar shifted just equals the associated transaction cost. Assuming, for simplicity, that these costs are quadratic, with $c_{i j}\left(s_{i j}\right)=\frac{1}{2} \Delta_{i j} s_{i j}^{2}$, the tax responsiveness of base shifting is given by:

$$
\frac{\partial s_{i j}}{\partial t_{j}}=-\frac{\partial s_{i j}}{\partial t_{i}}=\frac{1}{\delta(i, j)}>0,
$$

where $\delta(i, j) \equiv \Delta_{i j}+\Delta_{j i}$. The effect of a tax increase in some country $j$ on the base shifted into $i$, unlike that on real investment, is thus independent of either country's size, and of the real capital located in each, ${ }^{8}$ but depends only on the ease with which base can be artificially shifted between them. This too is intuitive: even a large advanced economy may be exposed to profit shifting as a result of low tax rates offered by a small island economy.

Combining these two sets of effects - on real investment and base shifting - the effect on country $i$ 's per capita tax base of an arbitrary small change $\left(d t_{1}, \ldots, d t_{n}\right)$ in all tax rates, $d b_{i}=h_{i} d k_{i}+d\left(\sum s_{i j}\right)$, can be written, using (4), (5) and (7) as:

\footnotetext{
${ }^{8}$ The separation of the decisions on $k_{i}$ and the $s_{i j}$ that emerges here is, of course, extreme, They would become linked if, as may be plausible, that shifting tax base into a county were easier if there is some real activity there.
} 


$$
\frac{d b_{i}}{h_{i}}=\beta_{i}\left(d t_{i}-\sum_{j \neq i} \omega_{i j} d t_{j}\right)
$$

where

$$
\beta_{i} \equiv-\left\{\left(1-h_{i}\right)+\sum_{j \neq i}^{n}\left(\frac{1}{h_{i} \delta(i, j)}\right)\right\}<0
$$

and

$$
\omega_{i j} \equiv \frac{h_{j}+\left(\frac{1}{h_{i} \delta(i, j)}\right)}{1-h_{i}+\sum_{p \neq i}\left(\frac{1}{h_{i} \delta(i, p)}\right)},
$$

The impact of any tax change on the tax base of country $i$ thus depends entirely on how it affects the difference between $i$ 's own rate and a weighted average of the tax rates in all other countries, with the structure of the weights $\omega_{i j}$ capturing the two distinct routes by which tax rate changes abroad can impact the tax base in $i$. This suggests an empirical strategy for distinguishing between them. If base effects operate only through real investment (as would be the case if the marginal costs of profit shifting $\delta$ were infinitely large), the weights become

$$
\omega_{i j}=\frac{h_{j}}{1-h_{i}}
$$

so that the impact of the tax rate in country $j$ on the domestic tax base in $i$ depends only on the size of $j$ relative to all countries other than $i$. If, in contrast, these impacts operate only through profit shifting (as would be case for a single country dwarfing all others) the appropriate weights become

$$
\omega_{i j}=\frac{1 / \delta(i, j)}{\sum_{p \neq i} \delta(i, p)}
$$

and it is tax rates in foreign countries weighted simply by the relative ease with which profits can be shifted in or out of them that matters.

One other implication of (9) is that the strength of the tax effects, captured in the $\beta_{i}$, will generally vary across countries; we also explore the possibility of systematic differences between, in particular, developing and other economies.

\section{B. Specification and Estimation}

Base spillovers are explored by estimating equations of the form:

$$
b_{i t}=\lambda b_{i t-1}+\varphi \tau_{i t}+\gamma \boldsymbol{W}_{-i} \boldsymbol{\tau}_{-i t}+\zeta^{\prime} \boldsymbol{X}_{i t}+\alpha_{i}+\mu_{t}+\varepsilon_{i t}
$$

where $b_{i t}$ denotes the corporate income tax (CIT) base in country $i=1, \ldots, n$ at time $t=$ $1, \ldots, L$ (with the lag allowing for sluggish response), $\tau_{i t}$ is the domestic CIT rate, $W_{-i} \tau_{-i t}$ 
denotes some weighted average $\sum_{j \neq i}^{n} \omega_{i j} \tau_{j t}$ of the statutory CIT rates in countries $j \neq i$ (with $\sum_{j \neq 1}^{n} \omega_{i j}=1$ ) and $\boldsymbol{X}_{i t}$ is a vector of controls. Country and time-specific effects $\alpha_{i}$ and $\mu_{t}$ are included in all regressions except where indicated. The analysis above implies that, for an appropriate choice of weights, $\varphi=-\gamma$; we allow these coefficients to differ in the base regressions (as might be plausible given, for instance, the presence of some immobile capital, not allowed for in the analytics), and treat this equality as a testable restriction.

With $\varphi$ in (13) being the short run marginal impact of a country's own CIT rate on its own CIT base, the long run impact is given by $\theta(\varphi) \equiv \varphi /(1-\lambda)$; both are expected to be negative. The focus here, however, is on base spillover effects from the tax rates set by others. This is captured by the coefficient $\gamma$ for the short run, and by

$$
\theta(\gamma) \equiv \frac{\gamma}{1-\lambda}
$$

for the long run, with both expected to be positive.

As analyzed above, the two channels through which such base spillover effects may operate - effects on real investment decisions, and on base shifting —imply different structures for the appropriate weighting matrix in (13), which provides a way to assess the importance of each. To capture the idea that spillover effects from foreign tax rates depend on relative country size, we construct the weighting matrix $\boldsymbol{W}_{-i}$ relevant for country $i$ in the spirit of equation (11), by weighting the tax rate in each foreign country $j$ by country $j$ 's GDP as a share of the total GDP of all countries other than i; we refer to these as GDP-weighted rates. ${ }^{9}$ To capture the possibility of spillovers through profit shifting, we consider two other weighting schemes: an unweighted average of statutory rates in all countries other than $i$, and - in the absence of direct data on the ease of shifting profits in and out of each country (the $\delta(i, j)$ above) - an unweighted average of rates only in those jurisdictions that are included in a commonly-used list of 'tax havens'; referred to as 'haven-weighted' rates. ${ }^{10} \mathrm{We}$ also consider the possibility that spillovers may be greater from geographically closer countries by weighting tax rates by the inverse-distance between capitals.

It should also be noted, however - a possibility not captured in the model above - that countries may in part react to changes in tax rates abroad by policy measures affecting their domestic tax base: special incentive schemes, for instance, or more generous deprecation.

\footnotetext{
${ }^{9}$ The use of GDP as an indicator of size is not entirely clean, since, as OECD (2015) notes, measured GDP may be affected by profit shifting (through, for instance, mispricing of exports and imports). This though seems likely to be of second order importance (certainly less marked than effects on GNP) and provides another reason for the instrumenting described below.

${ }^{10}$ The assumption in this case is thus it is equally easy to shift profits in/out of all 'havens', but impossible to shift profit through non-havens.
} 
These effects too will be captured in the empirics, though in the absence of detailed information on tax bases they cannot be measured directly.

We also explore - more briefly_-strategic rate spillovers, following Devereux and others (2008) in estimating

$$
\tau_{i t}=b \boldsymbol{W}_{-i} \boldsymbol{\tau}_{-i t}+\zeta^{\prime} \boldsymbol{X}_{i t}+a_{i}+c_{t}+\epsilon_{i t}
$$

but differing from previous work in considering the same four types of weighted average tax rates as for base spillovers. Though not formally modeled here, the reason for doing so is simply that one would expect rate-setting responses to be most sensitive to those tax rate choices abroad that most directly affect a country's own tax base. The specification in (15) includes the same controls as for the base spillover estimation and again includes country and time effects; as in the previous literature, the lagged dependent variable is omitted.

The empirical strategy just set out has significant limitations, largely reflecting those of the available data. Cross-border real investment decisions, for instance, are likely to be driven not by the statutory rate of CIT alone, but by an average effective tax rate (AETR) that also reflects depreciation and other allowances (Devereux and Griffith, 1998). Data on AETRs are not available, however, for as many countries or for as long a period as are statutory rates; and, as Dharmapala (2014) stresses, the dependence of calculated AETR on elements of the tax base creates a distinct endogeneity issue. Nonetheless, the use of AETRs, where available, rather than statutory rates can provide a useful additional perspective, and is pursued in Appendix 2.

Perhaps more troubling difficulties relate to the estimation of effects operating through tax havens. One is that the attractions of tax 'havens' do not solely, or even mainly, derive from low statutory CIT rates, but from special regimes and arrangements for which descriptive data are unavailable. ${ }^{11}$ The identification of haven effects thus depends on a plausible but (on our data) untestable correlation between movements in their statutory rates and special regimes. The results, for this reason, can be no more than indicative. A second difficulty is that the haven-weighted tax rate is the same, in each period, for all non-havens (for havens themselves, their own rate is of course excluded from the relevant average). This means that, with the inclusion of time effects, effects from havens are identified (given the restriction that

\footnotetext{
${ }^{11}$ The average CIT rate in the 'havens' is around 17 percent, compared to 32 percent for the full sample (Table 1). Many havens are small, however, and a low rate is common among smaller countries more generally. Regressing the CIT rate on country size (which enters with a significant positive coefficient, as models of tax competition would predict) and a dummy for tax haven status (and the using other controls being used), it emerges that tax-havens actually have, on average, a significantly higher CIT rate than otherwise similar countries.
} 
effects are identical across countries) only through their effect on other havens. We explore this further below.

Equations (13) and (15) are estimated by system generalized method of moments (GMM), using only internal instruments. While the panel is long enough that Nickell bias may not be a significant concern, other endogeneity issues arise. In the base spillover regression, shocks that affect a country's domestic tax base may also affect its contemporaneous tax rate choice, for instance; and the estimation of the CIT base by simply dividing revenues by the main statutory rate (as described below) can give rise to measurement error when, as is quite often the case, more than one CIT rate is applied. In the strategic rate spillover equation, tax rates are evidently jointly determined across countries. The results from fixed effect regressions, however, do not differ greatly from those from reported below for system GMM: the estimated coefficients are similar in both significance and size.

\section{Data}

The sample is an unbalanced panel comprising 173 countries over 1980-2013. The countries in the sample (and those labeled, following Gravelle (2013), as 'havens'), classified by income group, are listed in Appendix $1 .{ }^{12}$ Data on CIT revenues and statutory tax rates are from the IMF's Fiscal Affairs Department database. The country coverage of CIT rates is full, though unbalanced in the time dimension.

Resource-rich countries ${ }^{13}$ are excluded from the exercise in the sense that their tax bases are not treated as dependent variables, since they will likely have distinct drivers and reflect a variety of distinct tax design choices; importantly, however, the tax rates set by these countries are included in constructing the various average tax rates used as explanatory variables. As mentioned above, the CIT base in percent of GDP, $b_{i}$, is calculated by dividing CIT revenue in recent of GDP by the standard CIT rate; lack of revenue data means, however, that this is possible for only 121 countries. The data on average effective tax rates (AETR) used in Appendix 2, for 43 countries over the period 1996-2007 are from Abbas and Klemm (2013).

\footnotetext{
${ }^{12}$ The countries for which the AETR is available are: Argentina, Botswana, Brazil, Bulgaria, Chile, China, Colombia, Costa Rica, Czech Republic, Ecuador, Egypt, Estonia, Ghana, Hong Kong SAR, Hungary, India, Indonesia, Israel, Kenya, Korea, Latvia, Lithuania, Malaysia, Mauritius, Morocco, Namibia, Pakistan, Panama, Paraguay, Peru, Philippines, Poland, Senegal, Singapore, South Africa, Sri Lanka, Tanzania, Thailand, Turkey, Uganda, Ukraine, Uruguay, and Zambia.

${ }^{13}$ These are: Bahrain, Chad, Republic of Congo, Kazakhstan, Kuwait, Libya, Mexico, Nigeria, Norway, Oman, Russian Federation, Saudi Arabia, Syrian Arab Republic, Trinidad and Tobago, United Arab Emirates, and Venezuela.
} 
The controls $\boldsymbol{X}$ in (13) and (15), are ones that have commonly been used in modeling tax revenues and rates: ${ }^{14}$ (the log of) GDP per capita, the share of agriculture in value-added, trade openness (the sum of non-resource exports plus imports, relative to GDP), and inflation. $^{15}$

Table 1 provides descriptive statistics. The mean statutory CIT rate in the sample is 32 percent. The average of the GDP-weighted CIT rates is larger, reflecting somewhat higher CIT rates in larger countries (as the tax competition literature predicts). And the havenweighted average CIT rate is substantially lower, at 17 percent. The mean AETR is approximately 22 percent, lower than the mean statutory CIT rate (to be expected, since the AETR reflects various deductions in calculating the tax base). Figure 2 shows the movement of mean statutory CIT rates, by income group, over time. There has been a very pronounced decline, by over 20 percentage points over the last three decades, in all income groups. Despite these developments (or maybe as a result), Figure 1 above shows that revenue from the CIT tax has remained broadly stable in all income groups. Over the full sample, mean CIT revenue is around 2.6 percent of GDP, while the CIT base averages around 8.6 percent of GDP, with a fairly large standard deviation of 5.4.

Table 1. Descriptive Statistics

\begin{tabular}{lrrrrr}
\hline & Obs. & Mean & Max. & Min. & Std. Dev. \\
\hline Statutory CIT Rate, in percent & 3037 & 32.15 & 61.80 & 0.00 & 10.85 \\
GDP-weighted average tax rate, in percent & 3037 & 35.79 & 42.62 & 27.21 & 3.73 \\
Simple average CIT rate, in percent & 3037 & 29.10 & 37.25 & 20.41 & 4.86 \\
Haven-weighted average CIT rate, in percent & 3037 & 17.09 & 24.46 & 11.08 & 3.55 \\
CIT revenue, percent of GDP & 2161 & 2.64 & 13.37 & 0.00 & 1.53 \\
CIT base, percent of GDP & 2161 & 8.59 & 29.99 & 0.00 & 5.45 \\
$\quad$ OECD countries & 893 & 8.75 & 29.99 & 1.06 & 4.61 \\
$\quad 1268$ & 8.47 & 29.73 & 0.00 & 5.97 \\
$\quad$ Non-OECD countries & 1225 & 8.23 & 29.73 & 0.00 & 5.71 \\
$\quad$ Developing countries & 508 & 22.23 & 40.27 & -11.61 & 9.24 \\
AETR, in percent & 508 & 25.69 & 32.29 & 22.69 & 1.10 \\
GDP-weighted AETR, in percent & 508 & 21.68 & 25.20 & 1.54 & 3.08 \\
Simple average AETR, in percent & 1817 & 11.71 & 64.05 & 0.04 & 10.80 \\
Agricultural value-added, percent of GDP & 1970 & 13349 & 87716 & 126 & 15353 \\
GDP per capita, 2000 USD & 1974 & 79.04 & 436.95 & 6.32 & 45.66 \\
Trade openness, percent of GDP & 1925 & 36.46 & 11749.64 & -4.47 & 368.39 \\
Inflation, in percent & & & & & \\
\hline
\end{tabular}

\footnotetext{
${ }^{14}$ See, for example, Benedek and others (2014) and Crivelli and Gupta (2014).

15 The share of agriculture in aggregate value added is taken from the World Development Indicators (WDI) database; trade openness is calculated from the IMF's International Financial Statistics (IFS) database; per capita GDP is in constant (2000) U.S. dollars, taken from the WDI; inflation is the annual change in the consumer price index, taken from the IFS.
} 
Figure 2. Corporate Income Tax Rates, 1980-2013

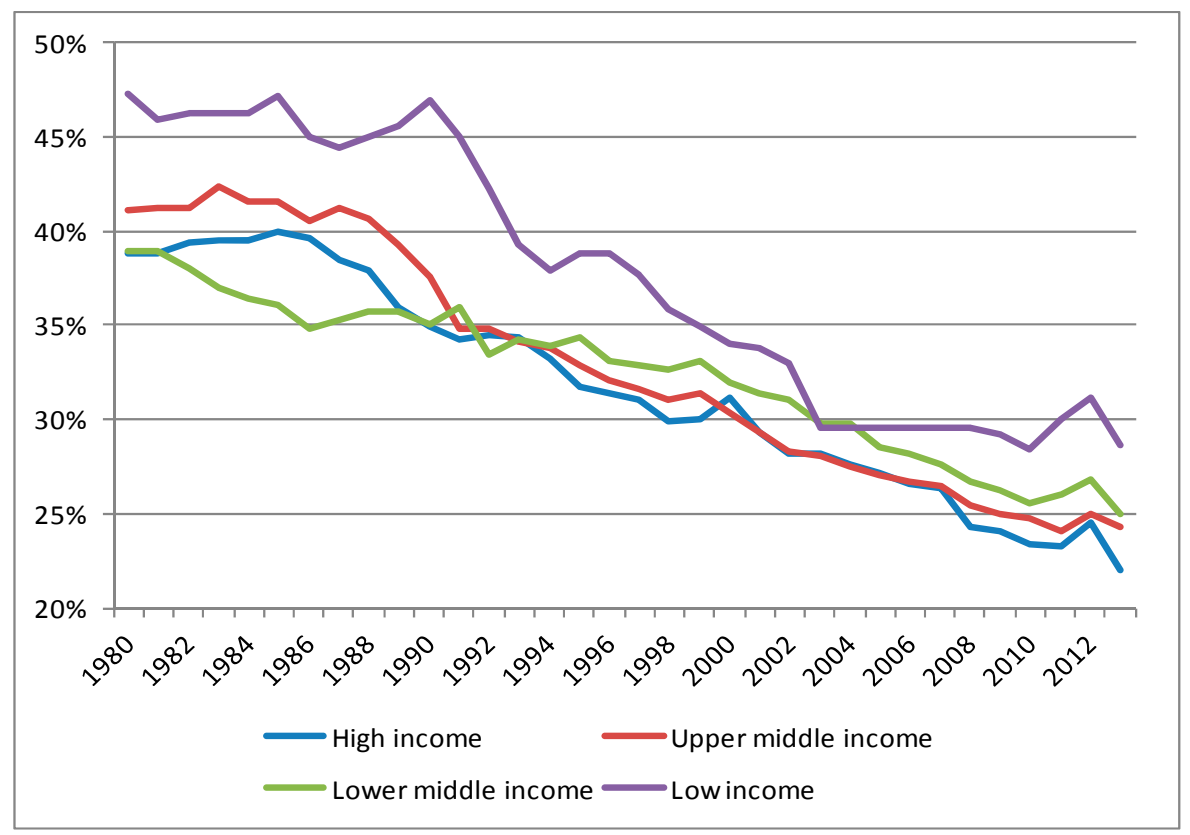

Source: IMF Staff estimates; data from IMF's Fiscal Affairs Department database.

\section{RESUlts}

This section present and discusses our empirical results, dealing in turn with base spillovers as in equation (13) and strategic rate spillovers as in equation (15). Results using AETRs rather than statutory CIT rates are reported in Appendix 2.

\section{A. Base Spillovers}

Table 2 reports the results of estimating (13) using the four different weighting matrices described above: column (1) uses GDP-weighted rates; column (2) the simple average; column (3) the haven-weighted average; and column (4) weights by the inverse distance between capital cities. The diagnostics are satisfactory in the Arellano and Bond (1991) tests for first- and second-order serial correlation (M1 and M2) and in the Hansen statistics. ${ }^{16}$ Most of the control variables in the regressions play no significant role in explaining corporate tax bases; the exception is trade openness, which is associated with a broader tax base in some of the regressions; for brevity, estimated coefficients on the controls are omitted in subsequent tables.

\footnotetext{
${ }^{16}$ The same is true for most results reported here. For cases in which the Hansen test is uncomfortably high, we also report the Sargan test which is less vulnerable to instrument proliferation, though not robust to heteroskedasticity (Roodman, 2009).
} 
Table 2. Base Spillovers with Alternative Weighting Matrices 1/

\begin{tabular}{|c|c|c|c|c|}
\hline & (1) & (2) & (3) & (4) \\
\hline CIT Base, lagged & $\begin{array}{l}0.7075^{* * *} \\
(0.1452)\end{array}$ & $\begin{array}{l}0.7828 * * * \\
(0.1084)\end{array}$ & $\begin{array}{l}0.7337 * * * \\
(0.0908)\end{array}$ & $\begin{array}{l}0.6783 * * * \\
(0.1091)\end{array}$ \\
\hline CIT rate $i$ & $\begin{array}{l}-0.1747 * * * \\
(0.0552)\end{array}$ & $\begin{array}{l}-0.1494 * * * \\
(0.0514)\end{array}$ & $\begin{array}{l}-0.0839 * * \\
(0.0439)\end{array}$ & $\begin{array}{l}-0.0935^{* *} \\
(0.0430)\end{array}$ \\
\hline CIT rate $j$, weighted GDP & $\begin{array}{l}0.3211^{* *} \\
(0.1693)\end{array}$ & & & \\
\hline CIT rate $j$, simple average & & $\begin{array}{l}0.1220^{*} \\
(0.0725)\end{array}$ & & \\
\hline CIT rate $j$, weighted tax havens & & & $\begin{array}{l}0.2973 * * * \\
(0.0971)\end{array}$ & \\
\hline $\begin{array}{l}\text { CIT rate } j \text {, weighted inverse- } \\
\text { distance }\end{array}$ & & & & $\begin{array}{l}0.2517 * * * \\
(0.0919)\end{array}$ \\
\hline Agriculture share & $\begin{array}{l}-0.2538 \\
(0.2120)\end{array}$ & $\begin{array}{l}0.2197 \\
(0.1847)\end{array}$ & $\begin{array}{l}0.0298 \\
(0.1262)\end{array}$ & $\begin{array}{l}-0.0527 \\
(0.0996)\end{array}$ \\
\hline GDP per capita $(\log )$ & $\begin{array}{l}-3.6608 \\
(2.3170)\end{array}$ & $\begin{array}{l}1.5651 \\
(1.6938)\end{array}$ & $\begin{array}{l}2.4947 \\
(1.8162)\end{array}$ & $\begin{array}{l}-0.7290 \\
(1.4816)\end{array}$ \\
\hline Trade Openness & $\begin{array}{l}0.0665^{* * *} \\
(0.0248)\end{array}$ & $\begin{array}{l}0.0353 * \\
(0.0211)\end{array}$ & $\begin{array}{l}0.0090 \\
(0.0139)\end{array}$ & $\begin{array}{l}0.0180 \\
(0.0169)\end{array}$ \\
\hline Inflation & $\begin{array}{l}0.0001 \\
(0.0005)\end{array}$ & $\begin{array}{l}-0.0010 \\
(0.0009)\end{array}$ & $\begin{array}{l}0.0005 \\
(0.0009)\end{array}$ & $\begin{array}{l}0.0006 \\
(0.0011)\end{array}$ \\
\hline$\theta(\varphi)$ & $\begin{array}{l}-0.5976^{*} \\
(0.3472)\end{array}$ & $\begin{array}{l}-0.6881 * * * \\
(0.2641)\end{array}$ & $\begin{array}{l}-0.3154 * * \\
(0.1396)\end{array}$ & $\begin{array}{l}-0.2908 * * * \\
(0.0950)\end{array}$ \\
\hline$\theta(\gamma)$ & $\begin{array}{l}1.0981^{*} \\
(0.9341) \\
\end{array}$ & $\begin{array}{l}0.5622^{*} \\
(0.3441)\end{array}$ & $\begin{array}{l}1.116^{* *} \\
(0.5146)\end{array}$ & $\begin{array}{l}0.7825 * * \\
(0.3367)\end{array}$ \\
\hline$\gamma=-\varphi(\mathrm{p}$ value $)$ & 0.303 & 0.691 & 0.055 & 0.107 \\
\hline Restricted Coefficient & $\begin{array}{l}0.1551 * * * \\
(0.0518)\end{array}$ & $\begin{array}{l}0.14433 * * * \\
(0.0490)\end{array}$ & $\begin{array}{l}0.1219 * * * \\
(0.0395)\end{array}$ & $\begin{array}{l}0.1184 * * * \\
(0.0401)\end{array}$ \\
\hline M1 (p value) & 0.000 & 0.003 & 0.000 & 0.001 \\
\hline M2 (p value) & 0.303 & 0.593 & 0.860 & 0.649 \\
\hline Over-identification & & & & \\
\hline Hansen ( $p$ value) & 0.710 & 0.620 & 0.272 & 0.256 \\
\hline Observations & 1547 & 1580 & 1570 & 1546 \\
\hline Number of instruments & 73 & 73 & 73 & 73 \\
\hline Number of countries & 102 & 103 & 103 & 101 \\
\hline
\end{tabular}

Note: Dependent variable is the CIT base. Full set of year dummies and control variables in all regressions. Robust standard errors, in parentheses; $* * *, * * *$ indicate significance at $1,5,10$ percent.

1/ One step, robust, system GMM with instruments based on first lag of differences in the CIT tax base (collapsed to avoid proliferation in the number of instruments) in levels equation, and second lags of their levels in the differenced equation.

The impact of country $i$ 's CIT rate on its own base is in all columns negative, significant and large. The short-run marginal coefficient of 0.17 in column (1), for instance, means that a one percentage point increase in a country's CIT rate will reduce its CIT base by 0.17 percent of GDP. Evaluated at a mean CIT base of 8.59 percent of GDP, this implies a (short run) semi- 
elasticity of the corporate tax base with respect to its own rate of $-2::^{17}$ that is, a one percentage point higher CIT rate reduces its own base by 2 percent. Sluggish response means that the long run effect is even larger: $\theta(\varphi)$ suggests, in column (1), an ultimate reduction of around 0.60 percent of GDP. The own-tax effects for the other weighting schemes, in columns (2) to (4), are smaller, ranging between -0.09 and -0.15 in the short run and between -0.3 and -0.7 in the long run-but are in all cases statistically significant.

The central concern here, of course, is with the base spillover effects, $\gamma$ and $\theta(\gamma)$. Column (1) shows a large and significant positive coefficient for the GDP-weighted average foreign tax rate, interpreted here as relating to spillovers through real capital flows: a one percentage point reduction in the GDP-weighted average CIT rate abroad reduces the typical country's CIT base in the short run by 0.32 percent of GDP: a short-run semi-elasticity of 3.7. These, by the standards of the literature for advanced economies reviewed in Dharmapala (2014), are large effects.

The base spillover effect becomes much smaller and less significant in column (2), where the same weight is attached to all foreign tax rates; which it was argued above may be a more appropriate formulation for capturing base spillovers through profit shifting. The short run semi-elasticity is now 1.4 .

Estimated base spillover effects in the haven-weighted case of column (3) are essentially the same as when using GDP-weights, though in some cases more significant.

In column (4) the estimated spillover effects when weighting tax rates by inverse distance are similar to those using GDP- and havens-weights, and again strongly significant.

Also reported in the table, and in those to follow, are the p-values from testing the restriction that $\varphi=-\gamma$ : the null that the base spillover and the own-tax effects are identical is close to rejection at standard significance levels only in the case of the haven- and inverse-distance weighted cases.

Two points stand out from these results. The first is that the long-run base spillover effects, between 0.56 and 1.11 percent of GDP, are large, as viewed for instance as a share of total tax revenue. The second is that both real and profit-shifting effects seem to be significant, and with a distinct haven effect emerging despite the imperfections, as noted above, with which the features of havens are captured in the data. Also notable is the importance of delayed response, with the large coefficients on the lagged dependent variable, which substantially increases the magnitude of impact (though being less precisely estimated). In

\footnotetext{
${ }^{17}$ Calculated as $(0.17 / 8.79) \times 100$.
} 
terms of speed of adjustment, the coefficient of 0.71 in column (1), for instance, implies a half-life of 2.4 years: that is, 50 percent of the adjustment is achieved after 2.4 years.

These results presume that tax effects are the same for all countries, which as noted earlier the theory suggests may not be the case. Of particular interest here is the possibility that these effects may vary systemically across counties at different income levels. How important are they, in particular, for developing countries?

To explore this, Table 3 reports results of estimating (13) for distinct subgroups of countries using haven-weighted tax rates; the results are similar using other weights. (with the weighted average tax rates in each case calculated over the full sample of countries). Results are shown for all countries (column 1, repeating column 3 of Table 2), OECD members (column 2), non-OECD countries (column 3), and developing countries ${ }^{18}$ (column 4).

Table 3. Base Spillovers by Income Level, 'Haven'-Weighted Tax Rates 1/

\begin{tabular}{lllll}
\hline & \multicolumn{1}{c}{ All } & \multicolumn{1}{c}{ OECD } & \multicolumn{1}{c}{ Non-OECD } & \multicolumn{1}{c}{ Developing } \\
\hline CIT Base, lagged & \multicolumn{1}{c}{$(1)$} & \multicolumn{1}{c}{$(2)$} & \multicolumn{1}{c}{$(3)$} & \multicolumn{1}{c}{$(4)$} \\
& $\left(0.0937^{* * *}\right.$ & $0.6041^{* * *}$ & $0.5271^{* * *}$ & $0.4994^{* * *}$ \\
CIT rate $i$ & $-0.0839^{* *}$ & $(0.1164)$ & $(0.1236)$ & $(0.1003)$ \\
& $(0.0439)$ & $(0.0421)$ & $(0.0640)$ & $(0.0888)$ \\
CIT rate $j$, haven & & & & \\
weighted & $0.2973^{* * *}$ & $0.1051^{*}$ & $0.2908^{* *}$ & $0.3119^{* *}$ \\
& $(0.0971)$ & $(0.0620)$ & $(0.1658)$ & $(0.1792)$ \\
\hline$\theta(\varphi)$ & $-0.3154 * *$ & $-0.1884^{* *}$ & $-0.3725^{* * *}$ & $-0.5155^{* * *}$ \\
$\theta(\gamma)$ & $(0.1396)$ & $(0.0935)$ & $(0.0998)$ & $(0.1481)$ \\
& $1.116^{* *}$ & $0.2657^{*}$ & $0.6566^{*}$ & $0.6231^{* *}$ \\
$\gamma=-\varphi$ (p value) & $(0.5146)$ & $(0.1689)$ & $(0.3799)$ & $(0.3143)$ \\
Restricted coefficient & 0.055 & 0.661 & 0.461 & 0.773 \\
& $0.1219 * * *$ & $0.0834^{* *}$ & $0.1773 * * *$ & $0.2663 * * *$ \\
\hline M1 (p value) & $(0.0395)$ & $(0.0371)$ & $(0.0617)$ & $(0.0839)$ \\
M2 (p value) & 0.000 & 0.001 & 0.001 & 0.010 \\
Over-identification & 0.860 & 0.585 & 0.324 & 0.567 \\
$\quad$ Hansen $(\mathrm{p}$ value) & 0.272 & 0.475 & 0.724 & 0.788 \\
Observations & 1570 & 641 & 932 & 954 \\
Number of instruments & 73 & 61 & 55 & 63 \\
Number of countries & 103 & 28 & 73 & 70 \\
\hline
\end{tabular}

Note: Dependent variable is the CIT base. Full set of control variables in all regressions. Including time fixed effects. Robust standard errors, in parenthesis; $* * *\left(* *,{ }^{*}\right)$ indicate significance at $1(5,10)$ percent.

1/ One step, robust, with instruments based on first lag of differences in the CIT tax base and CIT tax rates (collapsed to avoid proliferation in the number of instruments) in levels equation, and second lags of their levels in the differenced equation.

\footnotetext{
${ }^{18}$ Interpreted, recall, as in footnote 4.
} 
While the point estimates of the own-tax effect are much the same for OECD members in column (2) as for the full sample in column (1), though less significant, the base spillover effect is noticeably smaller and less significant: the long-run marginal impact coefficient, for instance, is 0.27 rather than 1.1 and significant at only ten rather than one percent.

Consistent with this, comparing columns (3) and (2) shows that estimated base spillovers are substantially larger for the non-OECD countries than for OECD: the short-term effect of 0.29 is nearly three times as large and the long-run impact more than twice as large. For developing countries (column 4), the short and long-term base spillover effects are about the same as for non-OECD countries, ${ }^{19}$ though the latter is somewhat more significant. Notable too is that for all subsamples the null of identical own- and spillover effects cannot now be rejected. Comparing the restricted coefficients for columns (3) and (2), that for non-OECD countries is twice as large as for OECD members (and more significant): the semi-elasticity of the former is 0.9 , comparable to the consensus in the previous literature, while that for the latter is 2.1 .

To explore the point noted earlier - that for non-haven countries variation in the spillover variable is likely to be highly correlated with time fixed effects - we have also run (but for brevity do not report) these regressions excluding time fixed effects. The results are qualitatively similar, but the estimated long-run spillover effect is between one- and twothirds smaller. Just as in Table 3, however, the base spillover is twice (or more) as large for non-OECD countries and lower income groups than for OECD countries.

Table 4 explores more closely the nature of the base spillover affecting developing countries, presenting results for each of the four weighting schemes used in Table 2. (Column (3) thus repeats column (3) of Table 3.

The results are similar to those for the full sample in Table 2 (though now the null of identical coefficients is always far from rejection). The largest base spillover effect is associated with GDP-weighted rates and the smallest with the unweighted average tax rate over all countries, though the variation in implied semi-elasticities is modest: between 2.6 and 3.5. Significance, however, is least for the GDP- and proximity-weighted average. Table 4 also shows suggests larger contemporaneous spillover and own effects and less sluggish response in developing countries.

\footnotetext{
${ }^{19}$ Moving from column (3) to (4) reduces the number of countries in the sample because some non-OECD countries are high-income, but increase the number of observations because a few OECD countries are middle income and with a good number of observations.
} 
Table 4. Base Spillovers in Developing Countries 1/

\begin{tabular}{|c|c|c|c|c|}
\hline & (1) & (2) & (3) & (4) \\
\hline CIT Base, lagged & $\begin{array}{l}0.5989 * * * \\
(0.0803)\end{array}$ & $\begin{array}{l}0.4120 * * * \\
(0.1267)\end{array}$ & $\begin{array}{l}0.4994 * * * \\
(0.1003)\end{array}$ & $\begin{array}{l}0.5004^{* * *} \\
(0.1247)\end{array}$ \\
\hline CIT rate $i$ & $\begin{array}{l}-0.1969 * * * \\
(0.0749)\end{array}$ & $\begin{array}{l}-0.3262 * * * \\
(0.0880)\end{array}$ & $\begin{array}{l}-0.2580 * * * \\
(0.0888)\end{array}$ & $\begin{array}{l}-0.2911 * * * \\
(0.0924)\end{array}$ \\
\hline CIT rate $j$, weighted GDP & $\begin{array}{l}0.5690^{*} \\
(0.3194)\end{array}$ & & & \\
\hline CIT rate $j$, simple average & & $\begin{array}{l}0.2075 * * \\
(0.1143)\end{array}$ & & \\
\hline $\begin{array}{l}\text { CIT rate } j, \text { weighted tax } \\
\text { havens }\end{array}$ & & & $\begin{array}{l}0.3119 * * \\
(0.1792)\end{array}$ & \\
\hline $\begin{array}{l}\text { CIT rate } j, \text { weighted } \\
\text { inverse distance }\end{array}$ & & & & $\begin{array}{l}0.2574 * \\
(0.1555) \\
\end{array}$ \\
\hline$\theta(\varphi)$ & $\begin{array}{l}-0.4910^{* *} \\
(0.2081)\end{array}$ & $\begin{array}{l}-0.5549 * * * \\
(0.1276)\end{array}$ & $\begin{array}{l}-0.5155^{* * * *} \\
(0.1481)\end{array}$ & $\begin{array}{l}-0.5829 * * * \\
(0.1880)\end{array}$ \\
\hline$\theta(\gamma)$ & $\begin{array}{l}1.4186^{*} \\
(0.7957) \\
\end{array}$ & $\begin{array}{l}0.3530 * * \\
(0.1787) \\
\end{array}$ & $\begin{array}{l}0.6231 * * \\
(0.3143) \\
\end{array}$ & $\begin{array}{l}0.5154^{*} \\
(0.3280) \\
\end{array}$ \\
\hline$\gamma=-\varphi(\mathrm{p}$ value $)$ & 0.252 & 0.411 & 0.773 & 0.829 \\
\hline Restricted coefficient & $\begin{array}{l}0.2132 * * * \\
(0.0735)\end{array}$ & $\begin{array}{l}0.2820 * * * \\
(0.0695)\end{array}$ & $\begin{array}{l}0.2663 * * * \\
(0.0839)\end{array}$ & $\begin{array}{l}0.2850 * * * \\
(0.0879)\end{array}$ \\
\hline M1 (p value) & 0.003 & 0.004 & 0.010 & 0.002 \\
\hline M2 (p value) & 0.502 & 0.463 & 0.567 & 0.259 \\
\hline Over-identification & & & & \\
\hline Hansen ( $p$ value) & 0.754 & 0.891 & 0.788 & 0.269 \\
\hline Observations & 915 & 954 & 954 & 953 \\
\hline Number of instruments & 63 & 70 & 63 & 60 \\
\hline Number of countries & 70 & 70 & 70 & 69 \\
\hline
\end{tabular}

Note: Dependent variable is the CIT base. Full set of control variables in all regressions. Robust standard errors, in parenthesis; $* * *(* *, *)$ indicate significance at $1(5,10)$ percent.

1/ One step, robust, with instruments based on first lag of differences in the CIT tax base and CIT tax rates (collapsed to avoid proliferation in the number of instruments) in levels equation, and second lags of their levels in the differenced equation.

The strong impression thus emerges that spillover effects, operating through both real and profit-shifting effects, matter at least as much for developing countries as for advanced. To explore the relative importance of these channels of effect more closely, Table 5 reports on a simple 'horse race' between the GDP-weighted and haven-weighted average tax rates; in column (1) for the full sample, in column (2) for developing countries only. These suggest primacy of avoidance over real effects, in the sense that when both are present it is only the haven-weighted average which emerge with significance. 
Table 5. Including both GDP- and Haven-weighted Averages 1/

\begin{tabular}{lll}
\hline & $(1)$ & $(2)$ \\
\hline CIT Base, lagged & $0.7845^{* * *}$ & $0.6281^{* * *}$ \\
CIT rate $i$ & $(0.0726)$ & $(0.0836)$ \\
& $-0.0712^{* *}$ & $-0.1734^{* * *}$ \\
CIT rate $j$, weighted GDP & $(0.0374)$ & $(0.0564)$ \\
$\gamma$ & -0.0215 & -0.0293 \\
CIT rate $j$, weighted tax havens & $(0.1239)$ & $(0.1989)$ \\
& $0.1286^{* *}$ & $0.1759^{* *}$ \\
$\theta(\varphi)$ & $(0.0605)$ & $(0.0791)$ \\
& $-0.3307^{*}$ & $-0.4665^{* * *}$ \\
$\theta(\gamma)$, havens & $(0.1840)$ & $(0.1855)$ \\
& $0.5970^{*}$ & $0.4731^{* *}$ \\
M1 (p value) & $(0.3854)$ & $(0.2089)$ \\
M2 (p value) & 0.000 & 0.003 \\
Over-identification & 0.995 & 0.773 \\
$\quad$ Hansen (p value) & & \\
Sargan (p value) & 0.635 & 1.00 \\
Observations & $\ldots$ & 0.158 \\
Number of instruments & 1570 & 915 \\
Number of countries & 97 & 85 \\
\hline
\end{tabular}

Note: Dependent variable is the CIT base. Full set of year dummies and control variables in all regressions. Robust standard errors, in parenthesis; $* * *(* *, *)$ indicate significance at $1(5,10)$ percent.

$1 /$ One step, robust, with instruments based on first lag of differences in the CIT tax base and CIT tax rates (collapsed to avoid proliferation in the number of instruments) in levels equation, and second lags of their levels in the differenced equation.

\section{B. The Revenue Cost of BEPS}

For all the importance attached to the issue in public debate and the recent high profile political initiatives, persuasive quantification of the revenue at stake through cross-border tax avoidance has proved elusive: Fuest and Riedel (2009), for instance, provide a forceful critique of many of the estimates that have been made. In one of the most careful exercises, Gravelle (2013) puts the loss to the U.S. from selected avoidance techniques at what was then around 25 percent of corporate tax revenues, which is roughly in the order of 0.6 percent of GDP.

The analysis here provides one simple, albeit highly speculative, way to size the possible effects of BEPS. Those avoidance effects operating through tax havens, at least, can in principle be assessed by simply 'turning off' the effects on tax bases operating through that channel, calculating the implied changes in tax bases, and multiplying by the applicable CIT 
rate. Conceptually, this corresponds to setting the profit shifting cost parameters $\delta(i, j)$ of the analysis above to infinity and evaluating the revenue impact at unchanged tax rates.

Table 6 reports the result of such an exercise, distinguishing between OECD and developing countries.

Table 6. Illustrative Revenue Loss Calculations

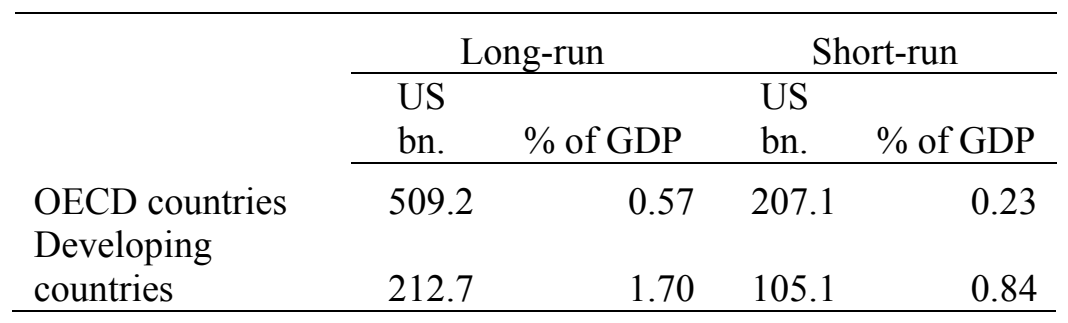

Note: Calculated using the restricted coefficients in Table 3

(columns (2) and (4)), and the statutory rates and estimated CIT bases of 2013.

The implied long run revenue losses for the advanced economies are in the order of 0.6 percent of GDP - strikingly close to the estimate of Gravelle (2013). Still more notable, however, is that the apparent revenue losses are much larger in developing countriesroughly three times as large, relative to their GDP - and, at close to 2 percent of GDP, very sizable. While there are of course many caveats to these estimates, with particular reservations related to the haven-weighting stressed above, the pattern of effects again suggests that the issues at stake may well be more pressing for developing countries than for advanced.

\section{Strategic Rate Spillovers}

Results on strategic rate spillovers - countries' rate-setting responses to the tax rates set elsewhere - are reported in Table 7 for the full sample of countries. Foreign tax rates are weighted in the same four alternative ways as above: by GDP (column (1)), unweighted across over all countries (column (2)), tax haven weights (column (3)) and by inverse distance (column (4)).

In all cases, the positivity and significance of the spillover coefficient indicates strategic complementarity in tax-setting: that is, countries respond to tax rate reductions elsewhere by cutting their own tax rate. In columns (2) and (4), for instance, a one percentage point reduction in the average CIT rate abroad, either unweighted or weighted by inverse-distance, induces a rate cut of around 0.5 points. There is a slightly larger response to rates in 'haven' countries (column 3) and a much larger, and more significant, response to the GDP-weighted average rate abroad. Indeed the coefficient in that case exceeds unity, though not significantly so. 
Table 7. Strategic Rate Spillovers, Alternative Weighting Matrices 1/

\begin{tabular}{lcccc}
\hline & $(1)$ & $(2)$ & $(3)$ & $(4)$ \\
\hline CIT rate $j$, weighted GDP & & & & \\
CIT rate $j$, simple average & $\begin{array}{c}1.2908^{* * *} \\
(0.5406)\end{array}$ & & & \\
& & $0.4649^{* *}$ & & \\
CIT rate $j$, weighted tax havens & & $(0.2197)$ & $0.6725^{* *}$ & \\
CIT rate $j$, weighted inverse-distance & & & $(0.4036)$ & \\
& & & & $0.4750^{* *}$ \\
& & & & $(0.2426)$ \\
M1 (p value) & 0.020 & 0.104 & 0.006 & 0.002 \\
M2 (p value) & 0.469 & 0.472 & 0.227 & 0.977 \\
Over-identification & & & & \\
$\quad$ Hansen (p value) & 0.650 & 0.189 & 0.115 & 0.454 \\
Observations & 2401 & 2203 & 2203 & 2178 \\
Number of instruments & 44 & 45 & 44 & 69 \\
Number of countries & 136 & 129 & 129 & 125 \\
\hline
\end{tabular}

Note: Dependent variable is statutory CIT rate. Full set of year dummies and control variables in all regressions. Robust standard errors, in parentheses; ${ }^{* * *}, * *,{ }^{*}$ indicate significance at $1,5,10$ percent.

1/ One step, robust, with instruments based on first lag of differences in the own CIT rate and weighted CIT rates of other countries (collapsed to avoid proliferation in the number of instruments) in levels equation, and second lags of their levels in the differenced equation.

Table 8 looks at the possibility of strategic rate spillovers differing across country groupings in this case using inverse-distance weighted tax rates, as in column (4) of Table 7; results are qualitatively similar for other weights. Column (2) shows an insignificant tax response for the sample of OECD countries; this contrasts with the finding of strategic complementarity within the OECD reported in previous studies (such as, for instance, Devereux et al. (2008)). In contrast, the strategic tax response in non-OECD countries is positive and significant (at five percent), and again around 0.5 . For low- and middle-income countries, the point estimate for the strategic spillover is larger, at almost 0.7 .

Strategic rate spillovers too thus appear, if anything, even greater for developing countries than for OECD members. 
Table 8. Strategic Rate Spillovers by Income Level, Inverse-Distance Weighted 1/

\begin{tabular}{lcccc}
\hline & All & OECD & Non-OECD & Developing \\
\hline & $(1)$ & $(2)$ & $(3)$ & $(4)$ \\
\hline CIT rate $j$, weighted inverse-distance & $0.4750^{* *}$ & -0.3303 & $0.5189^{* *}$ & $0.6622^{* *}$ \\
& $(0.2426)$ & $(0.3748)$ & $(0.2736)$ & $(0.3301)$ \\
M1 (p value) & 0.002 & 0.955 & 0.012 & 0.006 \\
M2 (p value) & 0.997 & 0.209 & 0.888 & 0.094 \\
Over-identification & & & & \\
$\quad$ Hansen (p value) & 0.454 & 1.000 & 0.278 & 0.576 \\
$\quad$ Sargan (p value) & $\ldots$ & 0.319 & $\ldots$ & $\ldots$ \\
Observations & 2178 & 705 & 1486 & 1395 \\
Number of instruments & 69 & 66 & 69 & 69 \\
Number of countries & 125 & 29 & 96 & 92 \\
\hline
\end{tabular}

Note: Dependent variable is statutory CIT rate. Full set of year dummies and control variables in all regressions. Robust standard errors, in parenthesis; $* * *(* *, *)$ indicate significance at $1(5,10)$ percent.

1/ One step, robust, with instruments based on first lag of differences in the own CIT rate and weighted CIT rates of other countries (collapsed to avoid proliferation in the number of instruments) in levels equation, and second lags of their levels in the differenced equation.

\section{Conclusions}

The core question posed at the outset was whether base erosion, profit shifting and international tax competition really matter for developing countries. The results presented here suggests, quite strongly, that they do - and, moreover, that they matter at least as much as for advanced economies. Base spillovers from others' tax rates, for example, emerge as two to three times larger in low-and middle-income countries than in OECD countries, and statistically more significant. And the signs are that these operate, in broadly equal measure, through effects on both real investment decisions and profit shifting. The revenue losses through avoidance activities associated with tax havens also seem larger outside the OECD; highly tentative estimates here put them in the order of a sizable one or two points of GDP. The results also suggest that strategic rate spillover effects too are stronger outside the OECD.

These conclusions are to a large degree tentative. The empirical characterization of 'haven' countries here, for example, does not fully capture the features making them attractive locations for profit shifting. More fundamentally, firm-level data, as is now routinely used to address international tax issues for advanced economies, would enable a much firmer grip on these issues. The difficulty is that this remains very scarce for developing countries, forcing reliance, at least for now, on cruder approaches of the kind explored here. 
The current policy debate on international tax issues is contentious and wide ranging, concerning not only specific problems within the current architecture - such as the challenges of implementing arms-length pricing and from treaty abuse-but also the appropriateness of that architecture itself. ${ }^{20}$ The results here do not speak directly to appropriate reconfiguration of international tax design. They do suggest, however, that developing countries have a considerable stake in the outcome.

\footnotetext{
${ }^{20}$ For discussion of these wider issues, see for instance Devereux and Vella (2014) and IMF (2014).
} 


\section{Appendix 1. Country Listing and Classification}

Low- and middle income countries: Afghanistan*, Albania, Algeria*, Antigua and

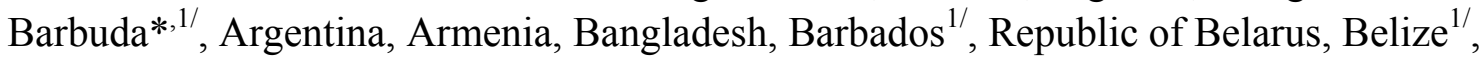
Benin*, Bhutan*, Bolivia, Bosnia and Herzegovina, Botswana, Brazil, Bulgaria, Burkina Faso*, Burundi*, Cambodia, Cameroon, Cabo Verde*, Central African Republic*, Chad*, Chile $^{*, 2 /}$, China, Colombia, Comoros*, Republic of Congo*, Costa Rica ${ }^{1 /}$, Côte d'Ivoire,

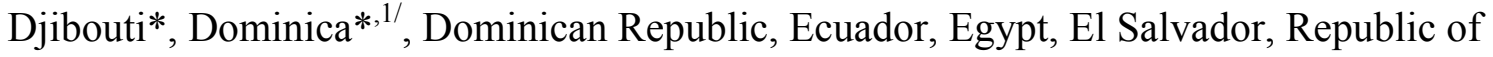
Equatorial Guinea*, Eritrea*, Ethiopia, Fiji, Gabon, The Gambia, Georgia, Ghana,

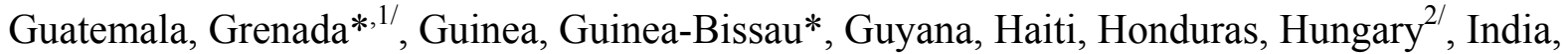
Indonesia, Islamic Republic of Iran, Iraq, Jamaica, Jordan ${ }^{1 /}$, Kazakhstan, Kenya*, Kyrgyz Republic, Lao P.D.R.*, Latvia, Lebanon*,1/, Lesotho*, Liberia*,1/, Libya*, Lithuania, Former Yugoslav Republic of Macedonia, Madagascar*, Malaysia, Malawi, Maldives*,1/, Mali*,

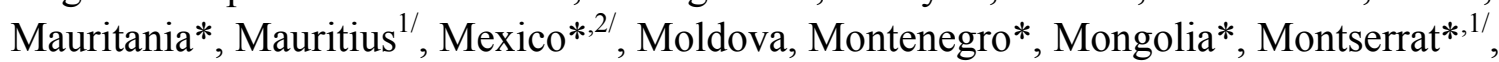
Morocco, Mozambique, Myanmar*, Namibia, Nepal*, Nicaragua*, Nigeria, Niger*, Pakistan, Panama ${ }^{1 /}$, Papua New Guinea, Paraguay, Peru, Philippines, Romania, Russian Federation, Rwanda*, São Tomé and Príncipe*, Senegal, Serbia*, Seychelles*,1/, Sierra Leone, Sri Lanka, Solomon Islands*, South Africa, St. Kitts and Nevis*,1/, St. Lucia ${ }^{1 /}$, St. Vincent and the Grenadines ${ }^{1 /}$, Swaziland, Syrian Arab Republic, Tajikistan*, Tanzania, Thailand, Togo*, Tonga*,1/, Tunisia, Turkey²/, Turkmenistan, Uganda, Ukraine, Uruguay Uzbekistan, Vanuatu*,1/, Venezuela, Vietnam, Yemen, Zambia, Zimbabwe.

High income countries: Australia ${ }^{2 /}$, Austria $^{2 /}$, The Bahamas ${ }^{1 /}$, Bahrain $^{*}{ }^{1 /}$, Belgium $^{2 /}$, Canada $^{2 /}$, Croatia, Cyprus ${ }^{1 /}$, Czech Republic ${ }^{2 /}$, Denmark ${ }^{2 /}$, Estonia $^{2 /}$, Finland ${ }^{2 /}$, France ${ }^{2 /}$, Germany $^{2 /}$, Greece ${ }^{2 /}$, Hong Kong SAR ${ }^{1 /}$, Iceland ${ }^{2 /}$, Ireland ${ }^{1 / 2 /}$, Israel ${ }^{2 /}$, Italy $^{2 /}$, Japan $^{2 /}$, Korea $^{2 /}$, Kuwait, Luxemburg ${ }^{1 /, 2 /}$, Malta ${ }^{1 /}$, Netherlands ${ }^{2 /}$, New Zealand ${ }^{2 /}$, Norway ${ }^{2 /}$, Oman, Poland $^{2 /}$, Portugal ${ }^{2 /}$, San Marino*,1/, Saudi Arabia*, Singapore ${ }^{1 /}$, Slovak Republic $^{2 /}$, Slovenia $^{2 /}$, Spain $^{2 /}$, Sweden $^{2 /}$, Switzerland ${ }^{1 /, 2 /}$, Trinidad and Tobago*, United Arab Emirates, United Kingdom $^{2 /}$, United States ${ }^{2 /}$.

Note: Classification by income group follows the World Bank. Data on CIT rates are available for all countries listed; * indicates that data on CIT revenue (and hence base) are not available; 1 / indicates countries labeled, following Gravelle (2013) as 'havens'; 2/ indicates an OECD member. 


\section{Appendix 2. Results Using Average Effective Tax Rates}

Focusing again only on developing countries, Appendix Table A1 presents results on base and strategic rate spillovers (in the first and last three columns respectively) using average effective tax rates (AETR) instead of the statutory rates used in the text. The sample becomes much smaller, but still contains 43 developing countries. Data limitations mean that in this case a haven-weighted average of AETRs cannot be constructed, so attention concentrates on the other three weighting schemes.

The results for base spillovers are largely consistent with the results in the text. In particular, the short-term base spillover effect when weighting ATERs abroad using GDP (column (1)) or inverse-distance (column (3)) is large, the former, for instance, taking a coefficient of 0.56 . This is very similar to the result in column (1) of Table 4; as is the long-run base spillover effect of 1.33. And the significance of the effects is now somewhat higher. When using the unweighted AETR (column (2)), the short-term base spillover coefficient falls, to 0.14 , but becomes more significant; this pattern is again similar to that in Table 4, though the coefficient there is somewhat higher, at 0.21 . Because adjustment is more sluggish, however, the long-run effect using the AETR is larger, and also proves more significant, than the estimates in either Table 4 or column (1).

On strategic rate spillovers, columns (4) and (6) indicate no significant effect from either GDP-weighted AETRs (which is consistent with previous results for advanced economies (Albrecht and Hochgatterer, 2012)) or from inverse-distance weighted rates. This last differs from the corresponding result (using statutory rates) in Table 8. Only for the unweighted average AETR (column (5)) is the effect significant, with a magnitude in line with the findings above for statutory tax rates. Signs of strategic rate-setting interactions thus seem somewhat stronger in relation to statutory tax rates than to AETRs. 
Appendix Table A1. Base and Strategic Rate Spillovers, using AETR 1/

\begin{tabular}{|c|c|c|c|c|c|c|}
\hline & $(1)$ & $(2)$ & (3) & $(4)$ & $(5)$ & $(6)$ \\
\hline & \multicolumn{3}{|c|}{ Base Spillover } & \multicolumn{3}{|c|}{ Strategic Spillover } \\
\hline CIT Base, lagged & $\begin{array}{l}0.5790 * * * \\
(0.2033)\end{array}$ & $\begin{array}{l}0.9092 * * * \\
(0.1268)\end{array}$ & $\begin{array}{l}0.6596 * * * \\
(0.2119)\end{array}$ & & & \\
\hline EATR $i$ & $\begin{array}{l}-0.0021 \\
(0.0085)\end{array}$ & $\begin{array}{l}0.0155 \\
(0.0450)\end{array}$ & $\begin{array}{l}-0.0990 \\
(0.1167)\end{array}$ & & & \\
\hline EATR $j$, weighted GDP & $\begin{array}{l}0.5612 * * \\
(0.2972)\end{array}$ & & & $\begin{array}{l}-1.3005 \\
(1.5650)\end{array}$ & & \\
\hline EATR $j$, simple average & & $\begin{array}{l}0.1431^{* * *} \\
(0.0551)\end{array}$ & & & $\begin{array}{l}0.6929^{* *} \\
(0.3990)\end{array}$ & \\
\hline $\begin{array}{l}\text { EATR } j \text {, weighted inverse- } \\
\text { distance }\end{array}$ & & & $\begin{array}{l}0.7384 * * \\
(0.3856)\end{array}$ & & & $\begin{array}{l}-0.0078 \\
(0.0181)\end{array}$ \\
\hline$\theta(\varphi)$ & $\begin{array}{l}-0.0049 \\
(0.0210)\end{array}$ & $\begin{array}{l}0.1711 \\
(0.3690)\end{array}$ & $\begin{array}{l}-0.2908 \\
(0.3538)\end{array}$ & & & \\
\hline$\theta(\gamma)$ & $\begin{array}{l}1.3334 * * \\
(0.6712)\end{array}$ & $\begin{array}{l}1.5759 * * * \\
(0.2154)\end{array}$ & $\begin{array}{l}2.1692^{*} \\
(1.6869) \\
\end{array}$ & & & \\
\hline$\gamma=-\varphi(\mathrm{p}$ value $)$ & 0.06 & 0.007 & 0.136 & $\ldots$ & $\ldots$ & $\ldots$ \\
\hline Restricted Coefficient & $\begin{array}{l}0.0830^{* * *} \\
(0.0325)\end{array}$ & $\begin{array}{l}0.0413 \\
(0.039)\end{array}$ & $\begin{array}{l}0.1846^{*} \\
(0.1016) \\
\end{array}$ & $\ldots$ & $\cdots$ & $\begin{array}{l}\cdots \\
\ldots \\
\end{array}$ \\
\hline M1 (p value) & 0.008 & 0.035 & 0.003 & 0.063 & 0.035 & 0.023 \\
\hline M2 (p value) & 0.177 & 0.385 & 0.194 & 0.913 & 0.655 & 0.338 \\
\hline Over-identification & & & & & & \\
\hline Hansen ( $p$ value) & 0.789 & 0.678 & 0.396 & 0.412 & 0.362 & 0.473 \\
\hline Observations & 271 & 305 & 305 & 400 & 400 & 397 \\
\hline Number of instruments & 37 & 30 & 41 & 24 & 25 & 26 \\
\hline Number of countries & 37 & 37 & 37 & 42 & 42 & 41 \\
\hline
\end{tabular}

Note: Dependent variable is the CIT base. Full set of year dummies and control variables in all regressions. Robust standard errors, in parenthesis; $* * *\left(* *,{ }^{*}\right)$ indicate significance at $1(5,10)$ percent.

1/ One step, robust, with instruments based on first lag of differences in the CIT tax base and CIT tax rates (collapsed to avoid proliferation in the number of instruments) in levels equation, and second lags of their levels in the differenced equation. 


\section{REFERENCES}

Abbas, S.M. Ali and Alexander Klemm, 2013, “A Partial Race to the Bottom: Corporate Tax Developments in Emerging and Developing Economies," International Tax and Public Finance, Vol. 20, pp. 596-617.

ActionAid, 2010, "Calling Time: Why SABMiller Should Stop Dodging taxes in Africa," November 28, 2010. Available via the Internet: https://www.actionaid.org.uk/sites/default/files/doc_lib/calling_time_on_tax_avoidan ce.pdf

Benedek, Dora, Ernesto Crivelli, Sanjeev Gupta, and Priscilla Muthoora, 2014, "Foreign Aid and Revenue: Still a Crowding-out Effect? FinanzArchiv, Vol.70, pp.67-96.

Blundell, Richard and Stephen Bond, 1998, "Initial Conditions and Moment Restrictions in Dynamic Panel Data Models," Journal of Econometrics, Vol. 87, pp. 115-43.

Brill, Alex and Kevin Hassett (2007), "Revenue-Maximizing Corporate Income Taxes: The Laffer Curve in OECD Countries", Working Paper No. 137, American Enterprise Institute for Public Policy.

Clausing, Kimberly, 2007, “Corporate Tax Revenues in OECD Countries”, International Tax and Public Finance, Vol. 14, pp. 115-34.

Crivelli, Ernesto and Sanjeev Gupta, 2014, "Resource Blessing, Revenue Curse? Domestic Revenue Effort in Resource-rich Countries," European Journal of Political Economy, Vol. 35, pp. 88-101.

De Mooij, Ruud and Sjef Ederveen, 2008, “Corporate Tax Elasticities: A Reader's Guide to Empirical Findings," Oxford Review of Economic Policy, Vol. 24 (4), pp. 680-97.

Devereux, Michael P., 2007, "Developments in the Taxation of Corporate Profit in the OECD since 1965: Rates, Bases and Revenues”, Working Paper No. 0704, Oxford University Centre for Business Taxation.

and Rachel Griffith, 1998, "Taxes and the Location of Production: Evidence from a Panel of U.S. Multinationals," Journal of Public Economics, Vol. 68, pp. 335-67.

Devereux, Michael P. and John Vella, 2014, "Are We Heading Towards a Corporate Tax System Fit for the 21st Century?” Fiscal Studies, Vol. 35, pp. 449-75.

Devereux, M., B. Lockwood, and M. Redoano, 2008, “Do Countries Compete over Corporate Tax Rates?” Journal of Public Economics, Vol. 92, pp. 1210-35.

Dharmapala, Dhammika, 2014, "What Do We Know About Base Erosion and Profit Shifting? A Review of the Empirical Literature," Fiscal Studies, Vol. 35, pp.421-48. 
Fuest, Clemens and Nadine Riedel, 2009, "Tax Evasion, Tax Avoidance and Tax Expenditures in Developing Countries: A Review of the Literature," Report prepared for the U.K. Department for International Development (DFID), (Oxford: Oxford University Centre for Business Taxation).

Gravelle, Jane, 2013, “Tax Havens: International Tax Avoidance and Evasion,” CRS Report for Congress, Congressional Research Service, United States.

Heckemeyer, Jost and Michael Overesch, 2013, "Multinationals' Profit Response to Tax Differentials: Effect Size and Shifting Channels," Centre for European Economic Research Discussion Paper No. 13-045 (Mannheim: Zentrum für Europäische Wirtschaftforschung $\mathrm{GmbH}$ ).

International Monetary Fund, 2014, "Spillovers in International Corporate Taxation," Available via the Internet at www.imf.org/external/np/pp/eng/2014/050914.pdf

Kawano, Laura and Joel Slemrod, 2012, "The Effect of Tax Rates and Tax Bases on Corporate Tax Revenues: Estimates with New Measures of the Corporate Tax Base," Oxford CBT Working Paper No 12/19.

Keen, Michael, and Kai Konrad, 2013, "The Theory of International Tax Competition and Coordination," pp. 257-328 in Handbook of Public Economics, Volume 5, ed. by A. Auerbach, R. Chetty, M. Feldstein, and E. Saez (Amsterdam: North Holland).

Klemm, Alexander and Stefan Van Parys, 2012, "Empirical evidence on the effects of tax incentives," International Tax and Public Finance, Vol. 19, 393-423.

Leibrecht, Markus and Claudia Hochgatterer, 2012, "Tax Competition as a Cause of Falling Corporate Income Tax Rates: A Survey of Empirical Literature," Journal of Economic Surveys, Vol. 26, 616-48.

Organisation for Economic Co-operation and Development, 2013, Action Plan on Base Erosion and Profit Shifting (OECD: Paris).

,2014, Report to the G20 Development Working Group on the Impact of BEPS in Low Income Countries, Parts 1 and 2 (OECD: Paris). , 2015, BEPS Action 11: Improving the Analysis of BEPS, Public Discussion Draft (OECD: Paris).

Redoano, Michela, 2007, "Fiscal Interactions among European Countries. Does the EU Matter?," CESifo Working Paper 1952.

Revelli, Federico, 2005, “On Spatial Public Finance Empirics," International Tax and Public Finance, Vol. 12, 475-92. 
Roodman, David, 2009, "A Note on the Theme of Too Many Instruments," Oxford Bulletin of Economics and Statistics 71(1), pp.135-58.

Schatan, Roberto, 2012, “Tax-Minimizing Strategies and the Arm's Length Principle," Tax Notes International, Vol. 65 (January 9) pp. 121-26. 